\title{
Mencermati Pelayanan Penyembuhan Pada Masa Kini
}

\author{
Daniel Susanto \\ Cipanas Theological Seminary \\ Email: daniel.susanto@ymail.com
}

\begin{abstract}
Pelayanan penyembuhan seringkali hanya dipahami secara fisik. Karena itu orang sakit sering mengharapkan penyembuhan yang biasa disebut dengan dengan curing. Padahal, tidak setiap penyakit dapat disembuhkan secara fisik. Walaupun demikian, orang sakit tetap dapat memperoleh penyembuhan atau healing, bila penyembuhan itu dipahami secara holistik. Penyembuhan holistik dilandasi pemikiran bahwa manusia tidak hanya mempunyai aspek fisik, tetapi juga aspek mental, sosial, dan spiritual. Karena itu penyembuhan holistik melebihi dari penyembuhan fisik. Bila penyembuhan fisik sudah tidak dapat dilakukan, orang yang sakit masih bisa mendapatkan penyembuhan, secara khusus penyembuhan aspek spiritualnya. Di dalam Alkitab disaksikan bahwa penyembuhan yang dilakukan Yesus tidak hanya bersifat fisik, tetapi juga holistik. Paulus tidak mengalami penyembuhan fisik ketika ia sakit. Namun ia mendapatkan penyembuhan secara spiritual dari Tuhan. Penyembuhan ini memungkinkan ia menilai secara potitif akan penyakit jasmani yang dideritanya. Ia bahkan bisa bersyukur dan melihat makna di balik penyakitnya itu. Karena orang sakit yang tidak bisa disembuhkan lagi secara medis masih bisa mendapatkan kehidupan spiritual bersama Tuhan, bagi orang beriman, kematian tidak lagi menakutkan. Pelayanan melalui hospice juga akan membantu dia dan keluarganya untuk menghadapi kematian.. Dalam kaitan dengan hal ini, gereja diharapkan menjadi penyembuh untuk melakukan pelayanan penyembuhan secara holistik yang bisa dikerjasamakan secara lintas iman. Dalam pelayanan ini, peran pendampingan pastoral menjadi sangat penting.
\end{abstract}

Keywords: penyembuhan, penyembuhan holistik, penyembuhan Yesus, Paulus, hospice, penyembuh, pendampingan pastoral

\begin{abstract}
Abstrak
Healing ministry is often only physically understood. Because of that sick people often expect healing which is commonly called curing. In fact, not every disease can be cured physically. However, sick people can still get healing, if healing is understood holistically. Holistic healing is based on the idea that humans not only have physical aspects, but also mental, social, and spiritual aspects. Because of that holistic healing is more than physical curing. If physical curing cannot be done, people who are sick can still get healing, specifically spiritual healing. In the Bible, it is witnessed that the healing done by Jesus was not only physical, but also holistic. Paul also did not experience physical curing when he was sick. However, he got spiritual healing from God. This healing allowed him to assess positively about his physical illness. He could even be grateful and saw the meaning behind the disease. Because sick people who cannot be cured medically can still get a spiritual life with God, for believers, death is no longer frightening. Services through hospice will also help him and his family. In connection with this, the church is expected to be a healer to carry out healing ministry in a holistic way that can be cooperated through interfaith. In this ministry, the role of pastoral care is very important.
\end{abstract}

Kata kunci: healing, holistic healing, Jesus' healing, Paul, hospice, healer, pastoral care 


\section{Pendahuluan}

Pelayanan penyembuhan sampai saat ini masih sering dipahami secara sempit dan terbatas. Penyembuhan terutama dimengerti sebagai penyembuhan fisik dan pelayanannya dilakukan oleh tenaga medis dengan peralatan yang canggih dan obatobatan yang beraneka ragam. Harapan orang untuk mendapatkan penyembuhan fisik memang sangat besar. Alasannya, karena orang pada umumnya tidak ingin merasakan sakit secara fisik dan tidak menghendaki kematian itu terjadi dalam hidupnya. Bukubuku tentang penyembuhan yang beredar di pasaran pada umumnya juga banyak yang difahami sebagai penyembuhan fisik belaka.

Untuk mendapatkan penyembuhan fisik, berbagai upaya dilakukan. Orang yang sakit mencari pengobatan baik secara medis maupun non-medis, baik di Indonesia maupun di luar negeri. Akhir-akhir ini berbagai iklan tentang penyembuhan, khususnya penyembuhan alternatif juga mulai menjamur di koran, di televisi, di majalah, dan sebagainya. Mereka berlomba-lomba untuk mendapatkan pasien yang ingin sembuh dari penyakitnya.

Mencari penyembuhan fisik tentu tidak salah. Setiap orang memang harus mempertahan-kan hidup yang Tuhan karuniakan kepadanya. Tetapi kalau penyembuhan fisik yang disebut dengan curing sudah tidak bisa lagi diupayakan, apakah tidak mungkin ada penyembuhan lain yang lebih luas dimensinya, yaitu healing? Apakah pelayanan penyembuhan pada masa kini hanya terbatas pada penyembuhan fisik belaka? Jawabnya tentu tidak, sebab di samping penyembuhan fisik masih ada penyembuhan holistik yang mencakup seluruh dimensi kehidupan manusia.

Artikel ini bertujuan mencermati bahwa penyembuhan fisik atau curing tidak cukup bagi seseorang. Pada waktu-waktu tertentu, di mana penyembuhaan fisik sudah tidak mungkin lagi diupayakaan, penyembuhan holistik masih bisa terjadi. Penyembuhan ini khususnya terjadi dalam arti spiritual.

\section{Pelayanan Penyembuhan}

Penyembuhan yang ditawarkan dan yang lebih dicari orang pada masa kini adalah penyembuhan fisik. Sebagai contoh, kalau seseorang menderita penyakit kanker atau jantung, yang pertama-tama ia cari adalah pengobatan untuk melenyapkan penyakitnya itu. 
Berbagai macam fasilitas pengobatan disiapkan bagi orang yang ingin mendapatkan kesembuhan. Pengobatan medis dapat diperoleh di mana-mana, tidak cuma di kota-kota besar tetapi juga di desa-desa. Jumlah rumah sakit dan puskesmas di Indonesia bertambah dari tahun ke tahun. Sebagai contoh, Kementerian Kesehatan R.I. melaporkan bahwa rumah sakit di Indonesia pada tahun 2015 berjumlah 2.490, sedang pada tahun 2016 meningkat menjadi 2.623 ${ }^{1}$. Jumlah dokter juga semakin banyak. Dokter yang tercatat di Indonesia sampai dengan 31 Desember 2017 berjumlah 192.879 orang. ${ }^{2}$ Peralatan medis dan laboratorium semakin lama juga semakin canggih, belum lagi jumlah obat-obatan yang semakin banyak jenisnya.

Penyembuhan fisik bisa memakan biaya yang besar. Biaya dokter, biaya rumah sakit, biaya pemeriksaan di laboratorium, biaya obat, dan sebagainya seringkali memberatkan hidup seseorang. Walaupun pemerintah telah memberikan jaminan kesehatan dan menyelenggarakan BPJS, pada kenyataannya belum semua orang bisa mendapatkan fasilitas kesehatan ini sepenuhnya. Alasannya tentu bermacam-macam, mulai dari ketidaktersediaan kamar perawatan sampai kepada persediaan obat yang terbatas.

Akhir-akhir ini, seiring dengan berkembangnya pengobatan medis, berkembang pulalah pengobatan herbal dan pengobatan alternatif lainnya. Klinik dan pengobatan alternatif bertebaran dan diiklankan di mana-mana. Penyembuhan ilahi juga ditawarkan oleh agama. Berbagai spanduk dipasang untuk menarik minat orang sakit datang kepada mereka.

Semua upaya penyembuhan ini hanya mempunyai satu tujuan, yaitu kesembuhan dari penyakit. Kita tentu memahami kalau orang sakit memang mengharapkan kesembuhan. Namun apakah kesembuhan fisik pasti bisa didapatkan, baik melalui pengobatan medis, pengobatan alternatif, maupun penyembuhan ilahi? Belum tentu, sebab segala sesuatu pada akhirnya ditentukan oleh Yang Maha Kuasa. Kepastian dalam hidup ini hanya ada dalam tangan Tuhan. Di samping itu, hidup

1 Direktorat Pelayanan Kesehatan Rujukan, Direktorat Pelayanan Kesehatan, Kementerian Keseharan RI, Laporan Akuntabilitas Kinerja Instansi Pemerintah Tahun 2016 - LAKIP 2016, http://depkes.go.id/resources/download/ LAKIP 2017, 6 (diakses 27 Januari 2019).

${ }^{2}$ Kementerian Kesehatan Republik Indonesia, Data dan Informasi - Profil Kesehatan Indonesia 2017, www.pusdatin.kemkes.go.id/resources/download/pusdatin/profil-kesehatan-indonesia/Data-danIndormasi_Profil-Kesehatan-Indonesia-2017.pdf (diakses 27 Januari 2019).

The New Perspective in Theology and Religious Studies, Vol. 1, No. 1, 2020 - 3 
manusia di dunia ini, termasuk fisiknya, juga terbatas. Karena itu manusia bisa jatuh sakit dan meninggal dunia.

Sebenarnya penyembuhan yang sesungguhnya adalah penyembuhan holistik yang melampaui penyembuhan fisik manusia. Penyembuhan holistik ini dilandasi oleh pemikiran tentang manusia yang juga bersifat holistik. Penyembuhan holistik akan mencakup penyembuhan spiritual yang bisa dialami seseorang sekalipun ia harus mengalami kematian secara fisik.

\section{Manusia Yang Membutuhkan Penyembuhan}

Sebagai orang yang percaya kepada Tuhan, kita yakin bahwa manusia diciptakan Allah menurut gambar dan rupa Allah (Kejadian 1:26). Apa maksudnya? Menurut G.C. van Niftrik dan B.J. Boland, dalam Kejadian 1:26 terdapat dua kata, yang masing-masing diterjemahkan dengan "gambar" dan "rupa." Sebenarnya dalam ayat ini terdapat suatu pengulangan seperti yang lazim digunakan dalam bahasa Ibrani, yaitu suatu pengulangan dengan kata-kata yang berbeda bunyinya, akan tetapi mempunyai arti yang sama ${ }^{3}$. Kedua ahli ini menolak anggapan "gambar Allah" sebagai sifat-sifat tertentu yang dimiliki oleh manusia. "Gambar Allah" harus diartikan sebagai hubungan tertentu, bukannya sebagai sifat-sifat tersebut ${ }^{4}$.

Ketika diciptakan, manusia berada dalam keadaan baik (Kejadian 1:31). Karena diciptakan segambar dan serupa dengan Allah, manusia mempunyai relasi yang baik dengan Allah. Serentak dengan itu, manusia mempunyai relasi yang baik dengan sesamanya, dengan lingkungan hidup di mana ia berada, dan dengan dirinya sendiri. Namun relasi yang baik ini telah dirusak oleh dosa manusia. Dosa telah menyebabkan rusaknya relasi antara manusia dengan Allah, manusia dengan sesamanya, manusia dengan alam, bahkan manusia dengan dirinya sendiri.

Dosa di taman Eden menyebabkan penderitaan, penyakit, dan kematian. Menjelaskan hubungan antara dosa dan penyakit, Erhard Schneider menyatakan bahwa menurut Perjanjian Lama, ada hubungan antara penyakit dengan dosa. Bukan maksudnya setiap penyakit manusia disebabkan dosa pribadi, tetapi yang benar ialah bahwa setiap penyakit adalah akibat pelang-garan di Taman Eden. Dengan adanya

\footnotetext{
${ }^{3}$ G.C. van Niftrik \& B. J. Boland, Dogmatika Masa Kini (Jakarta: BPK Gunung Mulia, 2010), 140. ${ }^{4}$ Ibid., 145 .
}

4 - The New Perspective in Theology and Religious Studies, Vol. 1, No. 1, 2020 
penyakit, kita diingatkan bahwa hubungan antara Allah dengan ciptaanNya telah terganggu. ${ }^{5}$

Tentang hubungan antara penyakit dan dosa pribadi, J.L. Ch. Abineno menyatakan: "Mungkin tidak mudah kalau kita katakan, bahwa pada umumnya tidak ada hubungan antara penyakit dan dosa atau kesalahan pribadi. Sebab dalam separuh kasus, hubungan itu ada. Dan kita tidak dapat menyangkalinya." ${ }^{6}$ Pertanyaan tentang hubungan antara dosa pribadi dengan penyakit memang seringkali menjadi pergumulan bagi orang yang sedang menderita penyakit berat. Dalam hal ini harus juga kita catat bahwa tidak setiap penyakit disebabkan oleh dosa pribadi. Kita ingat ketika Tuhan Yesus melihat seorang yang buta sejak lahirnya, murid-murid Tuhan Yesus bertanya kepadanya: "Rabi, siapakah yang berbuat dosa, orang ini sendiri atau orangtuanya, sehingga ia dilahirkan buta?" Jawab Yesus: "Bukan dia dan bukan juga orang-tuanya, tetapi karena pekerjaan-pekerjaan Allah harus dinyatakan di dalam dia." (Yohanes 9:2$3)$.

Manusia merupakan ciptaan Tuhan yang mempunyai berbagai aspek dalam hidupnya seperti aspek fisik, mental, sosial, dan spiritual. Keempat aspek ini saling berhubungan dan tidak dapat dipisahkan satu terhadap yang lain. Sebagai contoh, ketika seseorang menderita penyakit typhus, panas badannya naik (fisik), hatinya sedih (mental), niatnya untuk bertemu dengan orang-orang lain berkurang (sosial), tetapi keinginannya untuk berdoa meningkat karena ia ingin disembuhkan Tuhan (spiritual).

Dari dimensi-dimensi ini perlu dicatat bahwa dimensi spiritual memainkan peranan yang amat penting dalam kehidupan manusia, khususnya ketika ia sakit. Dimensi ini bisa mendatang-kan penghiburan dan kekuatan bagi orang yang sakit. Dimensi ini juga mampu memberikan pengharapan dan penyerahan kepada Tuhan.

Berbicara tentang dimensi spiritual, Beate Jacob menegaskan bahwa dimensi ini merupakan dimensi manusia yang sifatnya khusus dan merupakan dimensi manusia yang paling mengutuhkan. Keutuhan ini sangat ditekankan oleh Jacob. Ia menyayangkan kalau beragam bidang keilmuan yang bergerak dalam pengobatan membatasi pengertian kesatuan multi dimensi manusia pada satu tingkatan saja dengan

\footnotetext{
${ }^{5}$ Erhard Schneider, Maukah Engkau Sembuh? (Batu, Malang: Yayasan Persekutuan Pekabaran Injil Indonesia: Depertemen Literatur, 1992), 5.

${ }^{6}$ J.L.Ch. Abineno, Pelayanan Pastoral kepada Orang-Orang Sakit (Jakarta: BPK Gunung Mulia, 2003), 21.
}

The New Perspective in Theology and Religious Studies, Vol. 1, No. 1, 2020 - 5 
penekanan pada satu aspek dari kehidupan nyata. Pengobatan membatasi kesatuan multi dimensi pada tingkatan fisik dan psikoterapi pada tingkatan psikologis. ${ }^{7}$

Sebenarnya manusia tidak hidup sendiri dalam dunia ini. Ia hidup dalam sebuah masyarakat yang terdiri dari banyak orang. Ia juga berada di tengah-tengah lingkungan hidup yang kompleks. Karena kompleksnya relasi dalam diri manusia dan inter-relasi antara manusia, masyarakat, dan alam ciptaan Tuhan, holistisitas manusia harus dipahami secara interdisipliner. Berbagai ilmu yang mempelajari tentang manusia mempunyai peranan yang penting dalam mempelajari manusia secara holistik.

\section{Penyembuhan Holistik}

Setiap manusia pasti membutuhkan penyembuhan, apalagi ketika ia jatuh sakit. Walaupun demikian, pada umumnya orang masih memberi perhatian yang besar pada penyakit dan penyembuhan fisik, sedang penyakit dan penyembuhan mental, sosial dan spiritual masih kurang diperhatikan. Orang juga masih kurang memberi perhatian pada upaya pencegahan terhadap suatu penyakit, padahal mencegah itu jauh lebih baik dari pada mengobati.

Karena manusia bersifat holistik dan terdiri dari aspek fisik, mental, sosial, dan spiritual, manusia bisa sakit baik secara fisik, mental, sosial, maupun spiritual. Karena itu, penyembuhan terhadap semua aspek di atas sangatlah dibutuhkan. Untuk inilah penyembuhan yang bersifat holistik sangat dibutuhkan. Pelayanan pastoral yang dilakukan kepada orang ini juga harus bersifat holistik. ${ }^{8}$

Menurut William Clebsch dan Charles R. Jaekle, penyembuhan pada dasarnya merupakan upaya untuk mengatasi kerusakan yang dialami seseorang dengan cara memperbaiki orang tersebut menuju keutuhan dan membimbing orang tersebut mencapai keadaan yang lebih baik dari keadaan sebelumnya. ${ }^{9}$

Kerusakan di sini bisa saja kita sebut sebagai penyakit dan penyembuhannya ditujukan agar orang menjadi sehat. Sehat tentu lebih dari sekedar tidak adanya

\footnotetext{
${ }^{7}$ Beate Jacob, "Manusia Adalah Kesatuan Multi Dimensi - Gereja-gereja Kristen Mempunyai Pelayanan Penyembuhan Khusus", Penyembuhan Yang Mengutuhkan - Dimensi Yang Terabaikan Dalam Pelayanan Medis, ed. Rainward Bastian (Yogyakarta: Kanisius, 2003), h. 55-56.

${ }^{8}$ Daniel Susanto membahas tentang pelayanan pastoral holistik dalam tulisannya. Lihat: Daniel Susanto, "Pelayanan Pastoral Holistik," dalam Sekilas tentang Pelayanan Pastoral di Indonesia, ed. Daniel Susanto (Jakarta: Majelis Jemaat GKI Menteng Jakarta, 2010), 25-40.

${ }^{9}$ William A. Clebsch \& Charles R. Jaekle, Pastoral Care in Historical Perspective(New York: Harper \& Row, 1967), 33.
}

6 - The New Perspective in Theology and Religious Studies, Vol. 1, No. 1, 2020 
penyakit. Kenneth Vaux menulis pendapat WHO yang menyatakan bahwa sehat adalah suatu keadaan yang sempurna secara fisik, mental, dan sosial serta bukan hanya keadaan tanpa penyakit atau kelemahan. ${ }^{10}$

Selain WHO, para ahli juga memberikan pengertian mereka tentang orang yang dapat dikatakan sehat. Beate Jakob menuliskan pendapat beberapa ahli yang memandang kesehatan sebagai pengisian makna kehidupan dan menggambarkan kesehatan sebagai pemenuhan segala sesuatu yang membuat manusia berhasil dalam menemukan hakekat dan makna hidup. Sebagai contoh, U. Eibach mengatakan bahwa kesehatan adalah kekuatan untuk mengisi makna kehidupan yang diberikan. Demikian pula E. Schokenhoff menyatakan pendapatnya bahwa manusia sebagai seorang pribadi dikatakan sehat jika ia siap menghadapi tujuan hidupnya dan mampu menghadapi pengalaman-pengalaman yang sulit dan menyengsarakan. ${ }^{11}$

Dalam kaitan dengan pengertian ini, Jakob memaparkan konsep antropologis yang menyatakan bahwa manusia yang sehat membutuhkan hal-hal yang lebih dari sekedar fungsi fisik. Karena itu, mereka yang menggunakan konsep ini berpendapat bahwa kerusakan dalam fungsi fisik tidak terlalu menganggu kesehatan seseorang. ${ }^{12}$ Itu berarti, walaupun secara fisik seseorang mengalami penyakit fisik yang tidak bisa disembuhkan, ia masih bisa dikatakan sehat dan mengalami penyembuhan dalam dimensi yang lain.

Senada dengan pemikiran yang menghubungkan kesehatan dengan makna hidup, Jesudasan dan Ruppell memahami penyembuhan sebagai cara untuk memulihkan kembali kehancuran hidup. Penyembuhan adalah pencetakan kembali yang berguna. Cara ini bisa menutupi dan menemukan kembali keutuhan hidup seseorang secara integral dan utuh. ${ }^{13}$

\section{Penyembuhan Yang Dilakukan Yesus}

10 Kenneth Vaux, "Penyelidikan Kontek dan Konsep Kesehatan Holistik", dalam Dasar Theologis Perawatan Kesehatan Holistik, ed. Granger E. Westberg (Yogyakarta: RS Bethesda \& Pelkesi, 1985), 71.

${ }^{11}$ Beate Jakob, "Penyembuhan - Lebih Daripada Sekedar Mengunjungi Seorang Dokter", dalam Penyembuhan Yang Mengutuhkan, 65-66.

12 Ibid., 65.

${ }^{13}$ Usha Jesudasan \& Gert Rupell, Menjadi Penyembuh - Merengkuh Anugerah Allah dalam Penyembuhan (Surakarta: Yakkum Press, 2007), 23.

The New Perspective in Theology and Religious Studies, Vol. 1, No. 1, 2020 - 7 
Di dalam melakukan pelayanan-Nya, selain mengajar dan memberitakan Injil, Tuhan Yesus juga menyembuhkan banyak orang sakit. Hal ini disaksikan antara lain dalam Matius 4:23, "Yesuspun berkeliling di seluruh Galilea; Ia mengajar dalam rumah-rumah ibadat dan memberitakan Injil Kerajaan Allah serta melenyapkan segala penyakit dan kelemahan di antara bangsa itu." Dalam Matius 9:35 juga disaksikan: "Demikianlah Yesus berkeliling ke semua kota dan desa; Ia mengajar dalam rumahrumah ibadat dan memberitakan Injil Kerajaan Sorga serta melenyapkan segala penyakit dan kelemahan."

Penyembuhan yang dilakukanYesus bersifat holistik, mencakup seluruh aspek kehidupan manusia. Untuk melakukan penyembuhan ini Yesus tidak hanya menyembuhkan orang-orang yang secara fisik sakit seperti lumpuh, buta, kusta dan tuli, tetapi Ia juga menyembuhkan orang yang dirasuk setan, orang yang mengalami broken home, orang berdosa yang membutuhkan pengampunan, dan sebagainya.

Yesus memang menyembuhkan karena Ia menaruh belas kasihan kepada orang yang sakit dan orang yang menderita. Sebagai contoh, dalam Matius 14:14 disaksikan: "Ketika Yesus mendarat, Ia melihat orang banyak yang besar jumlahnya, maka tergeraklah hatiNya oleh belas kasihan kepada mereka dan Ia menyembuhkan mereka yang sakit". Dalam Markus 1:41-42 juga disaksikan: "Maka tergeraklah hatiNya oleh belas kasihan, lalu Ia mengulurkan tanganNya, menjamah orang itu dan berkata kepadanya: Aku mau, jadilah engkau tahir. " Seketika itu juga lenyaplah penyakit kusta orang itu, dan ia menjadi tahir."

Selain penyembuhan fisik, Yesus juga menyembuhkan orang yang mengalami broken home. Dalam Yohanes 4 disaksikan bahwa Yesus bercakap-cakap dengan seorang perempuan Samaria yang telah gagal dalam membina kehidupan pernikahannya. Lima orang telah menjadi suami perempuan ini, namun kelimanya tidak mendatangkan kebahagiaan dalam hidupnya. Yang terakhir, perempuan ini bahkan hidup bersama dengan laki-laki lain yang bukan suaminya. Dalam keadaan seperti ini, Yesus menyembuhkan perempuan itu dengan memberikan air hidup, yaitu keselamatan kepada perempuan ini.

Penyembuhan yang dilakukan Yesus berkaitan dengan keselamatan. Menurut Thomas A. Droege, kita telah terbiasa memakai istilah penyelamatan untuk jiwa. Tidak masuk akal bila kita mengatakan bahwa menyelamatkan juga terjadi untuk tubuh. 
Padahal, kata Yunani sodzo dalam Perjanjian Baru yang berarti menyelamatkan, dapat juga diartikan "membuat baik atau sembuh kembali". Jadi kata sodzo dapat dipakai dengan arti menyembuhkan. Arti menyembuhkan dari sodzo juga sering dipakai dalam Perjanjian Baru (Matius 9:22). ${ }^{14}$ Karena itu penyembuhan yang dilakukan Yesus sudah seharusnya kita mengerti dalam kerangka penyelamatan yang Yesus kerjakan.

Penyembuhan yang dilakukan Yesus juga berkaitan dengan Kerajaan Allah yang diberitakanNya. Droege menjelaskan hubungan antara penyembuhan yang dilakukan Yesus dengan pemberitaan Yesus tentang Kerajaan Allah. Penyembuhan merupakan peneguhan dari kebenaran wartaNya. Kuasa Allah diwujudkan melalui apa yang sedang dilakukan Yesus. Studi Dewan Gereja se Dunia (WCC) menyatakan bahwa penyembuhan Yesus adalah menyatakan tanda-tanda kuasa Allah yang sedang memasuki kehidupan manusia. ${ }^{15}$

Ketika menyembuhkan orang,Yesus tidak pilih kasih. Dalam Matius 4:24 disaksikan bahwa Yesus menyembuhkan semua orang yang datang kepadaNya. Dalam ayat ini disebutkan: "Maka tersiarlah berita tentang Dia di seluruh Siria dan dibawalah kepadaNya semua orang yang buruk keadaannya, yang menderita pelbagai penyakit dan sengsara, yang kerasukan, yang sakit ayan dan yang lumpuh, lalu Yesus menyembuhkan mereka".

Walaupun demikian, ada kalanya Yesus tidak menyembuhkan orang sakit fisik yang datang kepadaNya. Sebagai contoh, dalam Lukas 5:15-16 disaksikan: "Tetapi kabar tentang Yesus makin jauh tersiar dan datanglah orang banyak berbondongbondong kepadaNya untuk mendengar Dia dan untuk disembuhkan dari penyakit mereka. Akan tetapi Ia mengundurkan diri ke tempat-tempat yang sunyi dan berdoa." Ketika berada di Betesda, Yesus juga hanya menyembuhkan seorang yang sudah tiga puluh delapan tahun lamanya sakit, padahal di serambi kolam itu ada banyak orang sakit: orang-orang buta, orang-orang timpang dan orang-orang lumpuh yang menantikan kesembuhan (Yohanes 5:1-18). Ternyata tidak setiap penyakit fisik disembuhkan oleh Yesus dan ini merupakan suatu misteri. Kalau ini terjadi, Tuhan pasti punya maksud tertentu atas diri orang itu.

\footnotetext{
14 Thomas A. Droege, "Dasar Religius Perawatan Kesehatan Holistik", dalam Dasar Theologis Perawatan Kesehatan Holistik, 24-25.

${ }^{15}$ Ibid., 25
}

The New Perspective in Theology and Religious Studies, Vol. 1, No. 1, 2020 - 9 


\section{Penyembuhan Paulus}

Paulus termasuk salah satu orang yang tidak disembuhkan Tuhan secara fisik. Paulus menderita penyakit yang ia sebut sebagai "duri dalam daging”. Beberapa ahli menafsirkan penyakit Paulus ini. Paulus telah berupaya untuk mendapatkan kesembuhan atas penyakitnya. Sebagai orang beriman ia berdoa kepada Tuhan. Namun apa yang Tuhan berikan kepada Paulus tidak seperti apa yang ia harapkan. Paulus menyaksikan pengalaman imannya itu dalam 2 Korintus 12:8-9, "Tentang hal itu aku sudah tiga kali berseru kepada Tuhan, supaya utusan Iblis itu mundur dari padaku. Tetapi jawab Tuhan kepadaku: “Cukuplah kasih karuniaKu bagimu, sebab justru dalam kelemahanlah kuasaKu menjadi sempurna." Sebab itu terlebih suka aku bermegah atas kelemahanku, supaya kuasa Kristus turun menaungi aku."

Ternyata Tuhan tidak memberikan curing kepada Paulus, tetapi healing. "Duri dalam daging" Paulus tetap ada. Tetapi Paulus disembuhkan secara spiritual. Ada beberapa indikator dari penyembuhan yang dialami Paulus. Pertama, Paulus bisa menerima penyakitnya itu. Ia tidak mengeluh atau menyalahkan Tuhan. Ia juga tidak menyalahkan diri sendiri, seolah-olah ia telah berbuat dosa sehingga dihukum Tuhan dengan penyakit. Kedua, Paulus bisa memaknai penyakitnya itu secara positif. Ia melihat penyakitnya itu sebagai alat untuk bisa menyaksikan dan merasakan kuasa Tuhan di dalam hidupnya.

Penyakit yang diderita Paulus juga menyebabkan ia bisa menerima kesukaran dan penderitaan lain di dalam hidupnya. Ia menyatakan hal ini dalam 2 Korintus 12:10, "Karena itu aku senang dan rela di dalam kelemahan, di dalam siksaan, di dalam kesukaran, di dalam penganiayaan dan kesesakan oleh karena Kristus. Sebab jika aku lemah, maka aku kuat."

Itulah sebabnya Paulus tidak pernah takut dan gentar ketika ia memberitakan Injil Yesus Kristus, sekalipun ia harus mengalami berbagai tantangan, ancaman, kesukaran, penderitaan, bahkan kematian, ia berani menghadapi semuanya itu karena secara spiritual ia telah disembuhkan oleh Tuhan.

\section{Kematian Tidak Lagi Menakutkan}

Kalau tidak semua orang sakit bisa mendapatkan kesembuhan secara fisik, itu berarti penyakit yang diderita seseorang bisa menetap, bertambah parah, atau bahkan 
menyebabkan kematian. Kematian memang seringkali ditakuti orang. Banyak orang yang tidak siap untuk menghadapi kematian. Banyak di antara mereka yang bahkan tidak suka membicarakan tentang kematian. Tetapi untuk orang-orang yang percaya kepada Tuhan, apakah kematian secara fisik itu menakutkan? Tentu tidak.

Mengapa kematian tidak lagi menakutkan? Pertama, karena kematian merupakan akhir dari sebuah kehidupan di dunia yang akan dialami oleh semua orang, bahkan oleh semua makhluk. Kalau ada kelahiran, pasti ada kematian (Pengkhotbah 3:2-a). Tuhan Yesus sendiri sebagai manusia juga mengalami apa yang disebut dengan kematian itu.

Kedua, karena di dalam Kristus, orang percaya akan mendapatkan hidup kekal. Hidup kekal adalah hidup yang sesungguhnya, yang tidak akan berakhir dengan kematian di dunia ini. Dalam Yohanes 3:16 diberitakan: "Karena begitu besar kasih Allah akan dunia ini, sehingga Ia telah mengaruniakan Anaknya yang tunggal, supaya setiap orang yang percaya kepadaNya tidak binasa, melainkan beroleh hidup yang kekal."

Ketiga, kematian di dunia ini tidak menakutkan dan tidak merupakan akhir dari segala-galanya. Karena itu beberapa kali Tuhan Yesus menyebutkan kematian sebagai "tidur" saja Sebagai contoh, ketika Lazarus mati, Tuhan Yesus berkata kepada muridmuridNya: "Lazarus, saudara kita, telah tertidur, tetapi Aku pergi ke sana untuk membangunkan dia dari tidurnya" (Yohanes 11:11). Begitu juga ketika anak Yairus mati, Tuhan Yesus berkata kepada orang-orang yang ada di sana: "Mengapa kamu ribut dan menangis? Anak ini tidak mati, tetapi tidur!” (Markus 5:39).

Keempat, kematian merupakan kesempatan untuk beristirahat dari segala beban hidup di dunia ini. Dalam Wahyu 14:13 disaksikan Firman Tuhan: "Berbahagialah orang-orang mati yang mati dalam Tuhan, sejak sekarang ini. "Sungguh," kata Roh, "supaya mereka boleh beristirahat dari jerih lelah mereka, karena segala perbuatan mereka menyertai mereka.”

Kelima, kematian fisik tidak berlangsung selama-lamanya. Di dalam Kristus akan ada kebangkitan orang mati. Kehidupan sesudah kematian di dunia ini digambarkan begitu indah. Hal itu disaksikan Paulus dalam I Korintus 15:42-44, "Demikianlah pula halnya dengan kebangkitan orang mati. Ditaburkan dalam kebinasaan, dibangkitkan dalam ketidakbinasaan. Ditaburkan dalam kehinaaan, 
dibangkitkan dalam kemuliaan. Ditaburkan dalam kelemahan, dibangkitkan dalam kekuatan. Yang ditaburkan adalah tubuh alamiah, yang dibangkitkan adalah tubuh rohaniah."

Paulus tidak takut terhadap kematian. Kematian dianggapnya sebagai keuntungan (Filipi 1:21). Ia bahkan ingin mengalami kematian itu. Hal ini dikatakannya dalam Filipi 1:23-24, "Aku didesak dari dua pihak: aku ingin pergi dan diam bersamasama dengan Kristus - itu memang jauh lebih baik; tetapi lebih perlu untuk tinggal di dunia ini karena kamu."

\section{Hospice}

Dalam dunia kesehatan, bila seseorang mengalami penyakit yang secara medis tidak dapat disembuhkan lagi, ia bisa mendapatkan perawatan paliatif. Perawatan paliatif pada umumnya ditujukan untuk mengatasi gejala dan bukan lagi untuk mengatasi penyebab penyakitnya. Hospice merupakan salah satu sarana pelayanan bagi orang sakit terminal yang sudah menjelang ajal, sebelum ia mengalami kematian. Hospice juga memberikan pelayanan bagi keluarga pasien. Hospice mula-mula didirikan di Inggris oleh seorang dokter yang bernama Cicely Saunders dengan dibukanya St. Christopher's Hospice di London pada tahun $1967 .{ }^{16}$

Pelayanan di hospice tidak bermaksud memperpanjang umur pasien, tetapi untuk merawat dan mendampingi pasien agar ia dapat mengatasi penderitaannya baik secara fisik, psikis, sosial, maupun spiritual. Di samping itu pasien diharapkan untuk bisa meninggal dengan damai dan sejahtera. Pasien di hospice mendapatkan perawatan paliatif untuk mengurangi rasa nyeri, sementara ia juga mendapatkan pendampingan yang intensif dari para rohaniwan, psikolog, social worker, dan sebagainya.

Rumondang Panjaitan menjelaskan bahwa untuk mengatasi keluhan-keluhan fisik yang dirasakan pasien, seperti rasa nyeri yang hebat, mual, muntah, pendarahan, luka atau borok yang tidak kunjung sembuh, sakit kepala, diare, dan lain-lain, diperlukan tenaga dokter dan perawat. Untuk kenyamanan dan membebaskan pasien dari rasa nyeri yang hebat, mual, dan gangguan fisik lain sebagai akibat penyakit yang diderita, dokter memberikan obat penghilang nyeri, penghilang rasa mual, dan obat-obat

\footnotetext{
${ }^{16}$ Howard Clinebell, Basic Types of Pastoral Care and Counselling - Resources for the Ministry of Healing and Growth (London: SCM Press, 1984), 232.
}

12 - The New Perspective in Theology and Religious Studies, Vol. 1, No. 1, 2020 
lain sesuai dengan keluhan pasien. Jika ada luka atau borok yang tidak kunjung sembuh, perawat melakukan perawatan sesuai dengan kebutuhan pasien ${ }^{17}$.

Di samping keluhan fisik, pasien bisa mempunyai keluhan lain, seperti rasa sepi, takut, kecewa, cemas, marah, berdosa, dan sebagainya. Di sinilah peran pendamping, baik psikolog, social worker, maupun rohaniwan menjadi sangat penting. Rohaniwan sangat dibutuhkan untuk mendampingi pasien secara spiritual; untuk mendengarkan, memahami, dan mengasihi pasien; juga untuk membimbing dan menyiapkan jika pada suatu saat pasien dipanggil pulang oleh Yang Maha Kuasa. Rohaniwan dapat menolong pasien untuk mengatasi persoalan yang masih ada di dalam hati dan pikirannya.

Suasana di hospice dilukiskan dengan indah oleh Noortje Lumbantoruan. Menurut dia, suasana hospice adalah alami, manusiawi, dan bersifat pribadi. Pasien disambut ketika datang, dan disediakan tempat tidur sendiri yang sederhana dengan ukuran yang rendah. Di situ ada kamar-kamar keluarga dengan ruang terbuka untuk kegiatan-kegiatan kelompok. Jam kunjungannya juga dibuat bebas. Ada perhatian yang khusus akan sentuhan, percakapan pribadi, hubungan antar pribadi, kunjungan dan anak-anak. Setiap hari pakaian dan kebutuhan lainnya disediakan. Tidak ada penekanan kuat akan test diagnosa, rontgen, laporan laboratorium, terapi inovatif, dan sebagainya. Para penderita didukung, dikurangi rasa nyerinya, dan dikelilingi dengan perhatian dan keramahtamahan sebagai pendekatan-pendekatan akan kematian. ${ }^{18}$

Saat ini Yakkum, sebuah yayasan kesehatan yang dimiliki oleh Sinode Wilayah GKI SW Jateng dan GKJ, sedang menyiapkan berdirinya sebuah hospice di kota Solo. Hospice ini akan menjadi hospice pertama yang dimiliki oleh rumah sakit Kristen yang ada di Indonesia. Dengan pelayanan hospice, sebenarnya Yakkum ingin mewujudkan pelayanan kesehatannya secara holistik, yang dimulai ketika seseorang dilahirkan dan diakhiri pada saat seseorang mengalami kematian.

\section{Penyembuh}

Siapakah penyembuh bagi orang sakit? Pada dasarnya, penyembuh yang sesungguhnya adalah Tuhan sendiri. Walaupun demikian, Tuhan berkenan memakai

\footnotetext{
${ }^{17}$ Rumondang Panjaitan, Pelayanan Pastoral pada Pasien Terminal Menghadapi Kematian melalui Hospis, Karya Tulis Ahkir Magister Ministry di STT Jakarta, 2009, 89.

${ }^{18}$ Noortje Lumbantoruan, Pelayanan Pastoral Menjelang Ajal, Tesis Magister Theologiae di STT Jakarta, 2003.
}

The New Perspective in Theology and Religious Studies, Vol. 1, No. 1, 2020 - 13 
manusia untuk menjadi alatNya. Orang-orang ini bisa terdiri dari tenaga medis seperti dokter dan perawat, tenaga psikolog dan konselor, tenaga rohaniwan seperti pendeta, dan sebagainya. Karena penyembuh yang sesungguhnya adalah Tuhan, di dalam penyembuhan kita tidak boleh bergantung atau mengandalkan diri hanya kepada manusia, baik kepada dokter maupun kepada pendeta.

Sebagai hamba Tuhan, gereja dipanggil untuk melakukan tugas penyembuhan. Karena itu gereja tidak boleh melepaskan tanggung jawabnya dalam pelayanan penyembuhan ini. Menurut Jakob, gereja adalah komunitas penyembuhan yang mendorong tiap orang untuk menjadi manusia seutuhnya dan sempurna. Sebagai suatu komunitas penyembuhan, gereja memiliki potensi yang besar untuk memberi tempat bagi dimensi sosial dan spiritual-religius manusia serta dimensi fisik dan psikologisnya. ${ }^{19}$ Di dalam melakukan tugasnya sebagai penyembuh, gereja tentu bisa bekerjasama dengan komunitas lain, termasuk komunitas lintas iman.

Sebenarnya orang yang dipakai Tuhan untuk menjadi penyembuh bukanlah manusia yang sempurna. Karena itu Henri J. M. Nouwen menyebutkan bahwa penyembuh ini bisa juga terluka. Di dalam bukunya Nouwen menjelaskan bagaimana seorang yang terluka bisa menjadi penyembuh bagi sesamanya. ${ }^{20}$

Berbicara tentang agen-agen penyembuhan, Droege menjelaskan beberapa asumsi, sebagai berikut:

1. Pelayanan penyembuhan menuntut adanya suatu tim kerja yang multi disipliner.

2. Pekerja-pekerja profesional memiliki keahlian yang dapat dipakai untuk melakukan perawatan yang utuh.

3. Tanggung-jawab hidup sehat atau kesehatan pertama-tama adalah di pundak pasien dan pekerja medis adalah sebagai pembantu.

4. Siapapun dapat menjadi agen penyembuhan.

Tim kerja adalah sesuatu yang dasariah dalam perawatan kesehatan holistik. ${ }^{21}$

\section{Peran Pendampingan Pastoral}

\footnotetext{
${ }^{19}$ Jakob, "Penyembuhan - Lebih daripada Sekedar Mengunjungi Seorang Dokter", 73.

${ }^{20}$ Henri J.M. Nouwen, The Wounded Healer, Ministry in Contemporary Society (New York: Doubleday \& Company, 1972).

${ }^{21}$ Droege, "Dasar Religius Perawatan Kesehatan Holistik", 48-49. 
Walaupun peran tenaga medis sangat dibutuhkan dalam upaya penyembuhan, baik curing maupun healing, peran pendampingan pastoral terhadap orang yang sakit sangat penting. Pendampingan pastoral ini bertujuan memberikan pertolongan kepada orang yang sakit agar ia dapat memahami dan menggumuli penyakitnya bersama Tuhan. Istilah pastoral pada dasarnya mencerminkan pemeliharaan Allah terhadap ciptaanNya. ${ }^{22}$ Menurut John Patton, istilah ini menunjuk pada sikap yang memelihara (care) dan mempeduli-kan (concern). ${ }^{23}$ Pendampingan pastoral akan dilakukan sesuai dengan fungsi pastoral. Apa saja fungsi pastoral itu? Menurut Clebsch \& Jaekle, ada 4 fungsi dasar pastoral yang telah dipraktekkan di sepanjang sejarah, yaitu: menyembuhkan (healing), menopang (sustaining), membimbing (guiding), dan mendamaikan (reconciling). ${ }^{24}$

Fungsi menopang dan mendamaikan sangat penting dalam pendampingan pastoral bagi orang sakit, khususnya kalau penyakit orang itu secara medis sudah tidak bisa disembuhkan lagi. Orang yang mengalami penyakit seperti itu perlu ditopang. Topangan itu bisa terdiri dari penjagaan, penghiburan, penguatan, dan pemulihan. ${ }^{25}$

Orang yang sakit seperti ini juga sering bertanya-tanya tentang penyebab mengapa ia bisa mengalami penderitaan seperti itu. Tidak jarang orang ini menghubungkan penyakit yang dideritanya itu dengan dosa atau hukuman Tuhan atas dirinya. Kalau hal ini terjadi, itu merupakan pencarian akan Tuhan di dalam penderitaannya. Pertanyaan seperti ini sebaiknya dibiarkan terbuka di dalam pendampingan pastoral. Biarlah orang ini menggumuli pertanyaan itu bersama Tuhan.

Dalam keadaan sakit seperti ini, hubungan seseorang dengan Tuhan dapat menjadi terganggu. Orang itu bisa marah kepada Tuhan ketika doa-doanya tidak dikabulkan oleh Tuhan. Ia bisa kecewa kepada Tuhan atau bahkan menganggap Tuhan itu tidak ada lagi. Ia bisa menolak untuk berdoa, membaca Alkitab, dan sebagainya.

Dalam keadaan seperti ini, pendamping pastoral perlu mendengarkan dengan baik akan keluhan dan isi hati penderita. Ia tidak boleh menyalahkan atau menganggap negatif perasaan penderita. Sebaliknya, dengan sabar ia harus berusaha untuk

\footnotetext{
${ }^{22}$ Daniel Susanto, Pelayanan Pastoral di Indonesia pada Masa Transisi-Orasi Dies Natalis ke72 Sekolah Tinggi Teologi Jakarta (Jakarta: UPI STT Jakarta, 2006), 23.

${ }^{23}$ John Patton, From Ministry to Theology - Pastoral Action and Reflection (Nashville: Abingdon Press, 1990), 65.

${ }^{24}$ Clebsch \& Jaekle, Pastoral Care in Historical Perspective, 8-10, 32-66.

${ }^{25}$ Ibid., 43.
} 
mendamaikan kembali orang itu dengan Tuhan. Di sinilah fungsi pastoral reconciling coba diterapkan.

Pada saat orang yang sakit itu secara medis sudah tidak bisa disembuhkan lagi sementara penyakitnya menjadi bertambah berat, pendamping pastoral dapat tetap meminta pertolongan Tuhan sambil menyerahkan orang yang sakit ini ke dalam tangan Tuhan. Dalam rangka penyerahan kepada Tuhan, pendamping pastoral dapat mulai membicarakan baik kepada orang yang sakit maupun kepada keluarganya akan peranan healing yang lebih bermakna dari pada curing. Healing mencakup seluruh kehidupan walaupun bisa tanpa aspek fisik yang terbatas bila orang telah meninggal, sedang curing hanya terjadi secara fisik saja. Healing berlaku selamanya, sedang curing hanya terjadi di dunia. Pendamping pastoral dapat mengajak orang yang sakit dan keluarganya untuk bisa melepaskan penderitaan orang yang menderita ini agar bisa memasuki penyembuhan secara spiritual yang diberikan Tuhan. Dengan percakapan ini diharapkan orang yang sakit dapat menyerahkan hidup dan masa depannya ke dalam tangan Tuhan seperti yang pernah dialami juga oleh Yesus.

Percakapan tentang healing dan curing ini harus dilakukan ketika orang yang sakit dan keluarganya sudah siap untuk membicarakannya. Percakapan ini tidak boleh dipaksakan. Bila percakapan ini ternyata tidak bisa dilakukan, pendamping pastoral dapat mendoakan agar orang yang sakit itu bisa dibebaskan Tuhan dari penderitaannya. Dibebaskan bisa berarti curing, bisa juga healing, tergantung dari kehendak Tuhan.

\section{Kesimpulan}

Penyembuhan yang dapat dialami manusia sebenarnya bukanlah hanya penyembuhan fisik belaka, tetapi juga penyembuhan holistik yang mencakup aspek fisik, mental, sosial, dan spiritual. Penyembuhan yang dilakukan Yesus bersifat holistik. Memang, karena manusia adalah makhluk Tuhan yang bersifat terbatas, fisik manusia juga ada batasnya. Ketika seseorang sakit secara fisik, belum tentu ia bisa sembuh dalam arti mendapatkan curing, tetapi ia masih bisa mendapatkan kesembuhan dalam arti healing, khususnya pada aspek spiritualnya. Pada saat seseorang mati secara fisik, sebenarnya ia masih bisa hidup bersama Tuhan secara spiritual.

Ketika seseorang sakit secara fisik, biasanya ia akan mencari penyembuhan dalam arti curing. Tetapi ketika curing tidak terjadi, ia perlu mengusahakan healing 
pada aspek-aspek yang lain, khususnya pada aspek spiritualnya. Ia perlu merasakan penyertaanTuhan dan menggali makna positif dari penyakitnya itu, seperti yang pernah dialami Paulus.

Karena manusia masih bisa disembuhkan dalam arti spiritual, kematian fisik tidaklah menakutkan. Dalam dunia kesehatan, orang yang mengalami penyakit yang secara medis tidak bisa disembuhkan lagi, ia bisa mendapatkan perawatan paliatif dan pelayanan hospice. Melalui perawatan ini penderitaan orang itu dapat dikurangi dan ia dapat meninggal dengan damai dan sejahtera. Dalam pelayanan hospice, peran pendampingan pastoral dan penyembuh sangatlah dibutuhkan.

\section{Referensi}

Abineno, J.L.Ch., Pelayanan Pastoral kepada Orang-orang Sakit. Jakarta: BPK Gunung Mulia, 2003).

Clebsch, William A. \& Charles R. Jaekle, Pastoral Care in Historical Perspective. New York: Harper \& Row, 1967.

Clinebell, Howard, Basic Types of Pastoral Care and Counselling - Resources for the Ministry of Healing and Growth. London: SCM Press, 1984.

Droege, Thomas A., "Dasar Religius Perawatan Kesehatan Holistik", dalam Dasar Theologis Perawatan Kesehatan Holistik, ed. Granger E. Westberg. Yogyakarta: RS Bethesda \& Pelkesi, 1985.

Jacob, Beate, Penyembuhan Yang Mengutuhkan - Dimensi Yang Terabaikan dalam Pelayanan Medis, ed. Rainward Bastian. Yogyakarta: Kanisuis, 2003.

Jesudasan, Usha \& Gert Rupell, Menjadi Penyembuh - Merengkuh Anugerah Allah dalam Penyembuhan. Surakarta: Yakkum Press, 2007.

Nouwen, L Henri J.M., The Wounded Healer, Ministry in Contemporary Society. New York: Doubleday \& Company, 1972.

Lumbantoruan, Noortje, Pelayanan Pastoral Menjelang Ajal, Tesis Magister Theologiae di STT Jakarta, 2003.

Panjaitan, Rumondang, Pelayanan Pastoral pada Pasien Terminal Menghadapi Kematian melalui Hospis, Karya Tulis Ahkir Magister Ministry di STT Jakarta, 2009.

Patton, John, From Ministry to Theology - Pastoral Action and Reflection. Nashville: Abingdon Press, 1990.

Schneider, Erhard, Maukah Engkau Sembuh? Batu, Malang: Yayasan Persekutuan Pekabaran Injil Indonesia: Departemen Literatur, 1992.

The New Perspective in Theology and Religious Studies, Vol. 1, No. 1, 2020 - 17 
Susanto, Daniel, Pelayanan Pastoral di Indonesia pada Masa Transisi - Orasi Dies Natalis ke-72 Sekolah Tinggi Teologi Jakarta. Jakarta: UPI STT Jakarta, 2006.

- "Pelayanan Pastoral Holistik", dalam Sekilas tentang Pelayanan Pastoral di Indonesia, ed. Daniel Susanto. Jakarta: Majelis Jemaat GKI Menteng Jakarta, 2010.

Vaux, Kenneth, "Penyelidikan Kontek dan Konsep Kesehatan Holistik", dalam Dasar

Theologis Perawatan Kesehatan Holistik, ed. Granger E. Westberg. Yogyakarta: RS Bethesda \& Pelkesi, 1985.

18 - The New Perspective in Theology and Religious Studies, Vol. 1, No. 1, 2020 